\title{
Kardiovaskulêregesondheidsrisiko onder universiteitstudente in Suid-Afrika
}

\begin{abstract}
Authors:
Peet du Toit ${ }^{1,2,3,4}$

Elizabeth Rudolph ${ }^{5}$

Yvonne Joubert ${ }^{5}$

Nicoleen Coetzee $e^{1,2,3}$

Ernst Krüger ${ }^{2,6}$

Ronél Ferreira ${ }^{2,7}$

Evangeline Nortje $\mathrm{e}^{1,2,3}$

William Fraser ${ }^{2,8}$
\end{abstract}

\section{Affiliations:}

${ }^{1}$ Department of Physiology,

University of Pretoria,

South Africa

${ }^{2}$ Associate of the Institute for Food, Nutrition and Well-being, University of Pretoria, South Africa

${ }^{3}$ Associate of the Institute for Cellular and Molecular Medicine, University of Pretoria, South Africa

${ }^{4}$ Associate of the Exercise Smart Team, University of Pretoria, South Africa

${ }^{5}$ Department of Human Resource Management, University of South Africa, South Africa

${ }^{6}$ Department of Sport Research, University of Pretoria, South Africa

${ }^{7}$ Department of Educational Psychology, University of Pretoria, South Africa

${ }^{8}$ Department of Science, Mathematics and Technology Education, University of Pretoria, South Africa

Correspondence to: Peet du Toit

Email:

peet.dutoit@up.ac.za

Postal address:

PO Box 15875, Sinoville 0129, South Africa

\section{Read online:}

Tradisioneel is individue se vermoëns, belangstellings en persoonlikhede tydens beroepsvoorligting en werwings- en keuringsprosesse geassesseer, terwyl slegs enkele studies op die liggaamlike gesondheid van tweedejaarstudente, as intreevlakwerknemers vir sakeondernemings in SuidAfrika, gefokus het. Die hoofdoel van hierdie navorsing was om die stand van die kardiovaskulêre gesondheid van universiteitstudente in hul tweede jaar (as intreevlakwerknemers) te bepaal. Die motivering vir die studie was tweeledig: eerstens om die huidige kardiovaskulêre gesondheidsrisiko van studente te bepaal, en tweedens om hulle in te lig oor die mate van risiko waaraan hulle blootgestel is. Die studie was ' $n$ kwantitatiewe deursneestudie wat onderneem is om inligting in te win oor die kardiovaskulêre gesondheid van universiteitstudente. Die steekproef wat vir hierdie navorsingstudie gebruik is, het bestaan uit 162 universiteitstudente in Suid-Afrika wat almal tussen 18 en 25 jaar oud was. Die resultate het aangedui dat $55.6 \%$ van die betrokke studente aan hoë bloeddruk gely het. Uit laasgenoemde groep studente is $81.1 \%$ as prehipertensief gediagnoseer, terwyl stadium 1-hipertensie by $18.9 \%$ gediagnoseer is. Altesaam $64.8 \%$ van al die deelnemende studente se tellings is in die hoër meetgebied van die Kardiale Stresindeks (KSI). Ongelukkig het $61 \%$ van dié studente met verhoogde KSI-tellings ook hoë bloeddruk getoon. Benewens verhoogde harttempo en bloeddruk het $15.2 \%$ van die deelnemers ook swak harttempoveranderlikheid getoon. Dus het byna 10\% van die totale steekproef verhoogde kardiale stresvlakke, verhoogde harttempo en hoë bloeddrukvlakke vertoon. Die resultate dui daarop dat universiteitstudente heeltemal onbewus is van hul kardiovaskulêre gesondheid en van die moontlikheid dat dit 'n invloed op hul loopbane kan hê. Beroepsvoorligters, industriële sielkundiges, opvoedkundige sielkundiges en praktisyns op die gebied van menslikehulpbronbestuur kan hierdie inligting voordelig binne die bestek van hul praktyk gebruik om beroepsvoorligting aan fisiologiestudente te verskaf. Dié praktiese benadering sal fisiologiestudente ook in staat stel om vas te stel wat hul eie kardiovaskulêregesondheidsrisiko's is.

Cardiovascular health risk among university students in South Africa. Traditionally, individuals' abilities, interests and personality were assessed during career guidance and recruitment and selection processes; however, only a few studies focused on the actual health of second-year students, as entry-level employees for business in South Africa. The main research purpose was to determine the cardiovascular health of second-year university students' (as young entry-level employees). The motivations for the study are two-fold: to determine the current cardiovascular health risk of students, and to educate the students about such risk. The study was a quantitative cross-sectional study to determine university students' cardiovascular health. The sample used in this research study consisted of 162 university students in South Africa, between the ages of 18 and 25 years. The results indicated that $55.6 \%$ students had high blood pressure. Then $81.1 \%$ of the latter group of students were identified as prehypertensive, while $18.9 \%$ were considered as having stage- 1 hypertension. Students exhibited elevated cardiac stress as well. Altogether $64.8 \%$ of all the participating students scored in the elevated range of the Cardiac Stress Index (CSI). Unfortunately, $61 \%$ of the students with elevated CSI readings also exhibited high blood pressure. Furthermore, of the latter group, $15.2 \%$ exhibited poor heart rate variability, as well as elevated heart rate and blood pressure. Therefore, nearly $10 \%$ of the total sample exhibited elevated cardiac stress, an elevated heart rate and high blood pressure levels. The implications of the results are that university students are unaware of their cardiovascular health and that it may have an effect on their careers. Career counsellors, industrial psychologists, educational psychologists, and human resource management practitioners may benefit from this information in their scope of practice to guide physiology students in their career. This practical approach also allows physiology students to determine their own cardiovascular health risks.

Dates: Received: 02 June 2014 | Accepted: 12 Feb. 2015 | Published: 29 May 2015

How to cite this article: Du Toit, P., Rudolph, E., Joubert, Y., Coetzee, N., Krüger, E., Ferreira, R. et al., 2015, 'Kardiovaskulêregesondheidsrisiko onder universiteitstudente in Suid-Afrika', Suid-Afrikaanse Tydskrif vir Natuurwetenskap en Tegnologie 34(1), Art. \#1178, 7 pages. http:// dx.doi.org/10.4102/satnt.v34i1.1178

Copyright: @ 2015. The Authors. Licensee: AOSIS OpenJournals. This work is licensed under the Creative Commons Attribution License. 


\section{Inleiding \\ Sleutelfokus van die studie}

Is studente bewus van hul eie kardiovaskulêre siektestatus (KVS-status)? Tradisioneel fokus werwing, keuring en beroepsvoorligting op individue se vermoëns, belangstellings en persoonlikheid. In die beroeps- en arbeidswêreld is gesondheid egter belangrik en kan dit 'n uitwerking hê op mense se vermoë om hul beroepe doeltreffend en bekwaam te beoefen. Daar word moontlik aanvaar dat die risiko vir KVS laer is onder studente (intreevlakwerknemers), aangesien hulle as jonk, liggaamlik aktief en goed ingelig beskou word.

\section{Agtergrond vir die studie}

Die resultate van die studie impliseer dat universiteitstudente onbewus is van die stand van hul kardiovaskulêre gesondheid en van die feit dat dit moontlik hul loopbane kan beïnvloed. Daarbenewens blyk dit dat werkgewende organisasies, ondernemings en instansies ook geneig is om die kardiovaskulêre gesondheid van intreevlakwerknemers te ignoreer, aangesien hulle tydens werwing, keuring en beroepsvoorligting slegs op die sielkundige evaluering fokus. Dié studie was een van die eerste pogings om studente se bewustheid van die gevaar van KVS met hul keuse van ' $n$ beroep in verband te bring. Dit is 'n poging om werkgewende instansies se bewustheid van die risiko van KVS met die werwing en keuring van en beroepsvoorligting aan jong intreevlakwerknemers in verband te bring. Die akademiese implikasie van die studie is dat die maatskaplike, geestesen ekonomiese wetenskappe dié inligting kan gebruik om studente voor te berei om die komplekse situasie ten opsigte van die gevaar van KVS die hoof te kan bied. Daarbenewens is die doel van die inligting om werkgewende instansies en sielkundiges daarvan bewus te maak dat 'n interdissiplinêre benadering tydens die werwings- en keuringsprosesse en beroepsvoorligting nodig word.

Die meeste veldtogte wat gesondheidsbewustheid aanmoedig, word toegespits op persone bo 35-jarige ouderdom. In hierdie geval was die fokus egter op universiteitstudente in hul tweede jaar en het ons die kardiale stres, bloeddruk en harttempo van 162 sulke studente ondersoek. Die primêre doel was om inligting oor die kardiovaskulêre gesondheid van die studente in te win, terwyl die sekondêre doel was om hulle bewus te maak van hul eie kardiovaskulêre gesondheid en 'n geleentheid te skep om individue te identifiseer wat risikogevalle is.

Die bekendstelling aan die studie noodsaak 'n ondersoek na die agtergrond van KVS, die voorkoms van KVS onder studente en die negatiewe gevolge van KVS in die werkplek.

\section{Oorsig oor die navorsingsliteratuur Tendense volgens die navorsingsliteratuur wat verwys na KVS}

KVS is wêreldwyd 'n chroniese gesondheidsprobleem en is tans een van die hoofoorsake van sterftes (Kivimaki et al. 2002). Sommige van die risikofaktore gedurende die ontwikkeling van KVS sluit gevorderde ouderdom, hoë bloeddruk, diabetes, hipercholesterolemie, stres en liggaamlike onaktiwiteit in (Ainsworth \& Pettee Gabriel 2009). Daar bestaan 'n verband tussen psigososiale angs en KVS wat as ' $n$ belangrike gesondheidskwessie geïdentifiseer word (Brotman, Golden \& Wittstein 2007). Vorige navorsing is hoofsaaklik toegespits op hoe om KVS deur liggaamlike aktiwiteit te beheer en/of te bowe te kom (Du Toit et al. 2012). Desnieteenstaande is beperkte navorsing gedoen oor die mate waarin beroepsvoorligters bewus is van die gevaar van KVS onder voorgraadse studente.

\section{Tendense in navorsingsliteratuur wat verwys na welsyn met betrekking tot werwing, keuring en beroepsvoorligting}

Die welsyn van die werknemer is 'n belangrike faktor in die beroeps- en arbeidswêreld. Die Suid-Afrikaanse Wet op Beroepsgesondheid en Veiligheid (Wet nr. 85 van 1993) dwing werkgewende instansies om seker te maak dat werknemers in 'n veilige en gesonde omgewing werk. Gevolglik word slegs mediese toetse toegelaat wat betrekking het op die taakbeskrywing van die pos waarvoor 'n persoon aansoek doen. Industriële sielkundiges het alreeds die verband tussen die persoonlike faktor 'gesondheid' en ongelukke by die werkplek gedokumenteer (Schultz \& Schultz 2011). Schultz en Schultz (2011) het 'n positiewe verband tussen hoë werktevredenheid en veiligheidsbewustheid gerapporteer. Talle akademici is van mening dat sielkundiges die gesondheid van mense by die werk al 'n geruime tyd lank as 'n belangrike kwessie beskou (Arnold et al. 2010).

Soos vroeër verduidelik is, kan kardiovaskulêre siekte hartkwale veroorsaak wat tot die dood kan lei. Die verwagting is dat universiteitstudente, wat studeer om 'n kwalifikasie te verwerf, heel waarskynlik 'n gespesialiseerde veld in die arbeidsmark sal betree. As studente by wie KVS reeds gediagnoseer is egter tot die arbeidsmark toetree, sal hulle waarskynlik nie tot by aftreeouderdom kan werk nie. Vanuit 'n ekonomiese raamwerk beskou, is dit belangrik om geld te bespaar deur gesondheid vanaf binne organisasies te bestuur, om werknemers te help om optimale gesondheid te handhaaf en hul volle potensiaal te bereik, en ook om 'n veilige en gesonde werkplek te skep.

\section{Agtergrond vir kardiovaskulêre siekte}

'n Persoon se kardiovaskulêre stelsel is die netwerk wat die hart en die bloedvate (die hoofweg van die lewe) met mekaar verbind (Nevid, Rathus \& Greene 2008). Die hart funksioneer deur reëlmatige, ritmiese fases waartydens die hartspier afwisselend saamtrek en ontspan. Dit word die hartkringloop of kardiale siklus genoem en kan gehoor word deur na die klank van die hartkleppe te luister (Bergh 2011). Kardiovaskulêregesondheidsrisiko's is 'n veelvlakkige konsep wat op die individuele, span- en organisatoriese vlakke bestaan, met die gevolg dat dit 'n prioriteit is om die nodige kapasiteit te bou om navorsing op die gebied 
van gesondheidstelsels te onderneem. In Afrika suid van die Sahara is morbiditeit en mortaliteit weens kardiovaskulêre siekte aan die styg (Tibazarwa et al. 2009). Assessering, met die oog op die identifisering van risikofaktore, is ' $n$ belangrike werktuig wat gebruik word om die publiek op te voed oor die voorkoming en bestuur van kardiovaskulêre siektes.

\section{Kardiovaskulêre siekte onder studente (en die negatiewe uitwerking daarvan in die werkplek)}

Harttempo word beïnvloed deur faktore soos oefening, stres, emosionele opwinding, siekte en vrees (Bergh 2011). 'n Sektor wat met betrekking tot kardiovaskulêre siekte grotendeels oor die hoof gesien is, is universiteitstudente. Daar word waarskynlik aanvaar dat studente minder gevaar loop om kardiovaskulêre siektes te ontwikkel, aangesien daar aanvaar word dat hulle jonk, liggaamlik aktief en goed ingelig is. Die feit dat studente baie tyd aan sittende aktiwiteite soos klasbywoning bestee, verminder egter die beskermende uitwerking van liggaamlike aktiwiteit in hierdie populasie. Bykomend egter is daar bewyse dat jong mense nie so aktief is soos vermoed nie (Gaziano 1998). Afgesien van die dalende vlakke van fisieke aktiwiteit, is daar ook verdere ontstellende neigings in die gesondheidprofiel van jong mense, waaronder die verhoogde voorkoms van rook, vetsug (Gaziano 1998) en alkoholverbruik (Rustagi et al. 2011). Daarbenewens is daar bevind dat hoër opvoedingsvlakke nie noodwendig beteken dat mense meer bewus is van, of oortuig is van die voordele wat 'n gesonde leefwyse inhou nie (Steptoe et al. 2002). 'n Studie uitgevoer op mediese studente van Nepal het die hoë voorkoms van riskante kardiovaskulêre gedrag onder die studente getoon (Giri et al. 2012). Dié studie beklemtoon die dringendheid daarvan dat voorkomende kennis en praktyke onder studente bevorder moet word (Giri et al. 2012).

Beide genetiese en omgewingsfaktore lei tot die ontwikkeling van risikofaktore vir arterosklerotiese kardiovaskulêre siekte tydens kinderjare en jong volwassenheid (Daniels, Pratt \& Hayman 2011). Daniels et al. (2011) is van mening dat wanneer risikofaktore op ' $n$ vroeë ouderdom ontwikkel, hulle geneig is om met verloop van tyd versterk te word deur voortdurende nuwe nadelige gesondheidsgedrag, wat weer lei tot handhawing van die hoërisiko-status. Waarnemings vanuit die PDAJ-studie (Pathobiologiese Determinante van Arterosklerose in Jeug) toon 'n sterk verhouding tussen risikofaktore en anatomiese hartsiekte (McMahan et al. 2006). PDAJ-resultate bevestig vroeër waarnemings dat arterosklerose in die kinderjare begin en vorder deur adolessensie en jong volwassenheid. Baie jong volwassenes het reeds in hulle dertigerjare gevorderde koronêre arterosklerose (McGill Jr., McMahan \& Gidding 2008). Die outeurs is van mening dat ingryping in die vierde dekade en later eintlik sekondêre voorkoming is, aangesien gevorderde arterosklerose waarskynlik reeds teenwoordig is.

Waarnemings uit die Bogalusa-hartstudie verskaf geloofwaardigheid aan die eksaminering van jong persone om kliniese risikofaktore te meet en op 'n vroeë leeftyd met voorkomende kardiologie te begin (Berenson et al. 1992). Aangesien dit in volwassenheid moeilik is om baie lewenstylveranderinge te maak, en selfs moeiliker om hulle op die lang termyn te handhaaf, is dit billik om te probeer om hierdie risikofaktore vanaf 'n vroeë lewenstadium te verander. Verder is dit studies soos dié van Berenson et al. (1998) wat lei tot aansporing van die debat oor die belang van 'n behoorlike strategie vir openbare pogings wat die gesondheid van kinders en jong volwassenes verbeter.

Indien studente werklik verstaan wat ongewenste gesondheidsrisiko's is en dié kennis gebruik om hulself te bemagtig, kan persoonlike doelwitte en/of dié van werkgewende instansies doelwitte daardeur versterk word (Ferris et al. 2007). Kardiovaskulêre siekte wat morbiditeit (sieklikheid) en mortaliteit (sterftes) veroorsaak, is een van die ongewenste gesondheidsrisiko's in die geïndustrialiseerde wêreld (Schanalletal.2000). Ditis reeds'n pandemieendus'nopenbare gesondheidsprobleem. Na raming sal kardiovaskulêre siekte, wat in 1990 die tweede mees algemene oorsaak van sterftes was, teen 2020 die hoofoorsaak van sterftes wees. In die Verenigde State sterf tussen 250000 en 350000 mense jaarliks aan hartsiektes (Schanall et al. 2000). In Suid-Afrika was kardiovaskulêre siekte in 1991 die belangrikste oorsaak van sterftes in al die demografiese kategorieë, afgesien van die swart bevolkingsgroep, waar dit in die derde plek was. Kardiovaskulêre siekte het gevolglik 'n ernstige uitwerking op die Suid-Afrikaanse ekonomie (Pestana et al. 1996).

Beroepsvoorligters behoort nie net op die simptome en risiko's wat met KVS verbind word te fokus nie, maar moet seker maak dat hul kliënte ook bewus is van risikofaktore wat hart- en verwante funksies kan belemmer (Bergh 2011; Muchinsky 2006; Nevid et al. 2008).

Die dood van 'n werknemer by die werkplek het talle negatiewe gevolge vir die werkgewer, wat moontlik 'n werwingsproses van stapel sal moet stuur ten einde 'n toepaslik gekwalifiseerde en bevoegde persoon vir die betrokke posisie te vind. Daarbenewens sal die nodige opleiding aan die kandidaat verskaf moet word. Opleiding verwys hier na ' $n$ beplande poging tot verandering op die kort termyn wat ten doel het om houdings, oortuigings, vaardighede of kennis te wysig ten einde prestasie in 'n werkomgewing te verbeter (Coetzee et al. 2007).

Die dood van werknemers kan ook meebring dat hul kollegas trauma ervaar, wat ' $n$ negatiewe uitwerking op almal in die omgewing kan hê, aangesien getraumatiseerde werknemers berading kan nodig kry. Trauma kan ook hoë afwesigheid tot gevolg hê en individuele doeltreffendheid en prestasie benadeel. 'n Traumatiese gebeurtenis word omskryf as 'n gebeurtenis waartydens individue voel dat hul lewe of liggaamlike welsyn bedreig word, of die ervaring van 'n uiters emosionele versteuring weens die persoon se teenwoordigheid tydens 'n voorval toe iemand anders se lewe ernstig bedreig is of die persoon gesterf het (Hughes, Kinder \& Cooper 2012). 
Verskeie probleme wat onder werknemers voorkom (dwelmmisbruik, alkoholisme, KVS en hipertensie) veroorsaak hoër stresvlakke, laer produktiwiteit, meer afwesigheid en verhoogde personeelomset (Mostert et al. 2008; Wright \& Huang 2012). Ontleding van werknemers se risikofaktore en hulpbronne kan tot die vroeë opsporing van potensiële toekomstige risiko's lei (Voltmer \& Spahn 2011).

In die lig van bogenoemde literatuuroorsig kan die volgende navorsingsvraag gestel word:

Navorsingsvraag: Wat is die stand van tweedejaarstudente se kardiovaskulêre gesondheid wat betref bloeddruk, harttempo en kardiale stres?

\section{Navorsingsontwerp Navorsingsbenadering}

Die studie was 'n kwantitatiewe deursneestudie (Rindfleisch et al. 2008) wat onderneem is ten einde die kardiovaskulêre gesondheid van tweedejaarstudente te bepaal. In die geval van 'n deursneeontwerp moet een of meer steekproewe terselfdertyd uit die populasies getrek word. Die navorsers het die data wat uit die steekproewe verkry is, gebruik om die populasie op daardie tydstip te beskryf (Onyishi \& Ogbodo 2012).

\section{Navorsingsdoelwit}

Die doel van die navorsing was om tweedejaarstudente se KVS aan die hand van bloeddruk, harttempo en kardiale stres te meet. Tydens die proses is studente wat vir die fisiologiekursus ingeskryf het, bewus gemaak van hul kardiovaskulêre gesondheidstatus en is daar aan hulle gewys hoe KVS gekwantifiseer kan word.

\section{Navorsingsmetodes}

\section{Deelnemers aan die navorsing}

Die steekproef wat vir hierdie navorsingstudie gebruik is, het bestaan uit 162 voorgraadse universiteitstudente van tussen 18- en 25-jarige ouderdom wat in Suid-Afrika studeer. Toestemming vir die studie is van die Fakulteit Gesondheidswetenskappe se Navorsingsetiekkomitee verkry. Studente wat die kardiovaskulêre stelsel as deel van hul fisiologiekursus bestudeer het, het as deel van die praktiese vereistes vir die module aan die studie deelgeneem. Ingeligte toestemming is voor hul deelname van die studente verkry en hulle is versoek om voor toetsing stil te sit en 'n biografiese vraelys te voltooi.

\section{Meetinstrumente en navorsingsprosedure}

Kardiovaskulêre gesondheid is ondersoek deur van meetinstrumente vir kardiale stres, bloeddruk (BD) en harttempo gebruik te maak. Die Kardiale Stresindeks (KSI) en harttempo is gemeet deur 'n Viport te gebruik. Die Viportinstrument meet ook hartritme en harttempo (Du Toit et al. 2012). Terwyl die subjekte regop in 'n sittende posisie was, is die boonste twee elektrodes van die Viport op hul eerste interkostale (tussenrib-) spasie geplaas. Die lesing is twee minute lank geneem terwyl die subjekte normaal asemgehaal het en skielike bewegings of spraak vermy is. Viport is innoverendehart-enstressiftingstegnologiewat doeltreffende en vinnige elektrokardiograafgebaseerde (EKG-gebaseerde) assesserings van die hart se gesondheid moontlik maak (Du Toit et al. 2012). Die KSI is 'n sensitiewe stresaanduider en word as analoog aan harttempoveranderlikes beskou (Du Toit et al. 2012; Rudack 2005).

Bloeddruklesings is met behulp van 'n sfigmomanometer (bloeddrukmeter) geneem. Die absolute lesings is opgeteken en aan die hand van die riglyne van die Gesamentlike Nasionale Komitee vir die Voorkoming, Opsporing, Evaluasie en Behandeling van Hoë Bloeddruk as normotensief, prehipertensief of hipertensief gegradeer (JNC 7 Express 2003). Daar is omsigtig opgetree om te verseker dat subjekte met abnormale lesings nie onnodig ontstel sou word nie. In die lig van die feit dat enkele bloeddruklesings in tot soveel as $66 \%$ van gevalle vals positiewe lesings vir hipertensie kan gee (JNC 7 Express 2003), is die bloeddruk van subjekte met 'n sistoliese lesing van meer as $120 \mathrm{mmHg}$ of 'n diastoliese lesing van meer as $80 \mathrm{mmHg}$ drie keer gemeet om die resultaat te bevestig (die gemiddelde van dié drie lesings is vir analise gebruik), en is hulle aangeraai om hul dokters te raadpleeg. Om te verseker dat die opvoedkundig praktiese doel van die toetsing bereik is, het die studente ook vooraf ' $n$ verpligte praktiese lesing bygewoon wat gedurende klastyd geskeduleer is.

\section{Statistiese analise}

Statistiese analise is uitgevoer deur van SPSS 17.0 gebruik te maak (Pallant 2005). Beskrywende data is vir die hele steekproef bereken. Die steekproef is daarna volgens KSIlesings in twee groepe verdeel. Tussengroepverskille is bepaal deur van die t-toets $(p \leq 0.05)$ vir onafhanklike steekproewe gebruik te maak. Die waarskynlikheidsverhouding vir KSI en hipertensie is bereken.

Resultate: Die steekproef het uit 129 vroue en 33 mans van tussen 18- en 25-jarige ouderdom bestaan (gemiddelde ouderdom $=20.419$ j.; SA [standaardafwyking] $=1.102$ ) . Die gemiddelde KSI $(36.099 \%$; SA $=24.131)$ is bo die aanvaarde perk vir gesonde kardiale stres (20\%). Die gemiddelde harttempo, asook die sistoliese en diastoliese bloeddrukmetings is binne hul onderskeie aanvaarde perke. Die gemiddelde harttempo is 83.093, SA = 14.792; die gemiddelde sistoliese BD is $119.889 \mathrm{mmHg}$, SA = 12.649 en die gemiddelde diastoliese BD is 72.901, $\mathrm{SA}=9.943$.

Die resultate is volgens twee groepe KSI-resultate verdeel normale lesings $(\mathrm{KSI} \leq 20 \%$ ) en swak KSI-lesings (KSI > $20 \%)$. Die twee groepe is met mekaar vergelyk deur gebruik te maak van die $t$-toetse $(p<0.05)$ vir onafhanklike steekproeftoetse. Die gemiddelde standaardafwyking (SA) en $p$-waarde vir ouderdom, harttempo en bloeddruk vir die twee groepe word in Tabel 1 geillustreer. Die twee het 
TABEL 1: Die gemiddelde standaardafwyking en $p$-waarde vir ouderdom, harttempo en bloeddruk oor die Kardiale Stresindeks-groepe heen.

\begin{tabular}{lcccc}
\hline Veranderlike & KSI-klas (\%) & Gemiddelde & Standaardafwyking & $p$-waarde \\
\hline Ouderdom (j) & $\leq 20$ & 20.3273 & 1.23310 & 0.404 \\
& $>20$ & 20.4808 & 1.02380 & \\
Harttempo (spm) & $\leq 20$ & 74.8182 & 8.76249 & 0.001 \\
& $>20$ & 87.3868 & 15.47445 & \\
Sistoliese BD & $\leq 20$ & 119.2364 & 12.00149 & 0.618 \\
(mmHg) & $>20$ & 120.2925 & 13.05444 & \\
Diastoliese BD & $\leq 20$ & 70.6364 & 8.90352 & 0.032 \\
(mmHg) & $>20$ & 74.1698 & 10.27570 & \\
\hline
\end{tabular}

BD, bloeddruk; KSI, Kardiale Stresindeks.

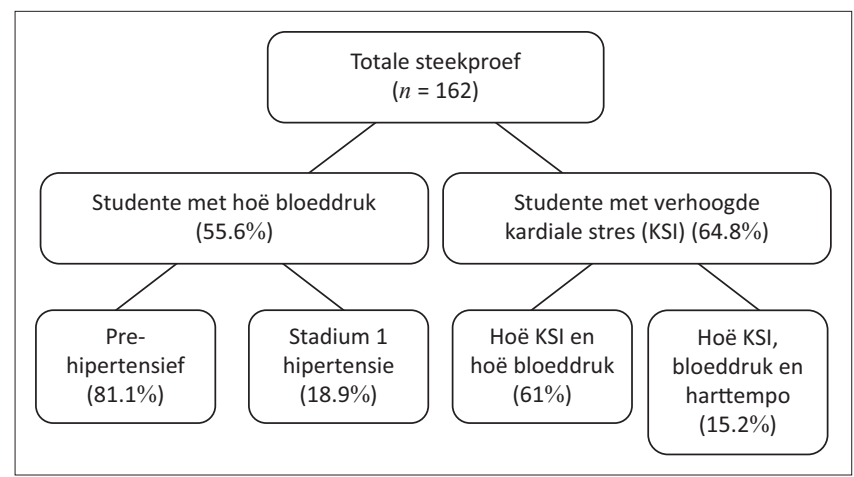

FIGUUR 1: Indeling van persentasie studente met hoë bloeddruk en Kardiale Stresindeks.

aansienlike verskille getoon ten opsigte van harttempo en diastoliese bloeddruk.

Die waarskynlikheid van hoë bloeddruk (prehipertensie of hipertensie) en KSI is bereken. Die waarskynlikheidsverhouding is 1.73 .

Alhoewel die gemiddelde lesings vir harttempo en bloeddruk binne aanvaarbare perke was, het $55.6 \%$ van die studente hoë bloeddruk gehad (Figuur 1). Van die 55.6\% met hoë bloeddruk is $81.1 \%$ onderskeidelik as prehipertensief en 18.9\% met stadium 1-hipertensie geïdentifiseer (Figuur 1). Daarbenewens het $64.8 \%$ van die deelnemende studente verhoogde kardiale stres getoon (Figuur 1).

KSI is analoog met harttempoveranderlikheid (HTV) (Rudack 2005). KSI $\leq 20 \%$ weerspieël normale HTV, terwyl KSI $>20 \%$ verminderde HTV aandui en sodoende verhoogde kardiovaskulere risiko. Lae HTV word met kardiovaskulêre siekte geassosieer (Umetani et al. 1998). Ongelukkig het 61\% van die studente met hoë KSI-lesings ook hoë bloeddruk gehad (Figuur 1). Die waarskynlikheidsverhouding vir hoë bloeddruk (prehipertensie of hipertensie) wanneer KSI groter as $20 \%$ is, is 1.73 . Dit dui daarop dat studente met hoë KSI 1.73 keer meer waarskynlik hoë bloeddruk (prehipertensie en hipertensie) sal hê as studente met normale KSI.

Slegs enkele studente se harttempo's was verhoog en net $14.2 \%$ se harttempo's was bo 100 spm, maar 69.6\% van dié studente het ook met hoë KSI en bloeddruk gepresenteer. Dus, uit die $64.8 \%$ van studente wat hoë KSI getoon het, het $15.2 \%$ ook verhoogde harttempo en hoë bloeddruk vertoon
(Figuur 1) - wat byna 10\% van die totale steekproef is. Die twee KSI-groepe het aansienlik verskil ten opsigte van harttempo $(p=.001)$ en diastoliese $\operatorname{BD}(p=.032)$. In albei gevalle was die lesings hoër vir die groep met KSI > 20\%. Ouderdom het geen uitwerking op die resultate gehad nie $(p=.404)$.

\section{Bespreking}

'n Mens se kardiovaskulêre stelsel verbind nie net die hart en bloedvate nie (Arnold et al. 2010), maar het ook 'n invloed op morbiditeit en mortaliteit (Tibazarwa et al. 2009). Die kardiovaskulêre risiko's waaraan studente blootgestel word, maak dit noodsaaklik om 'n netwerkstelsel tussen die maatskaplike wetenskappe, geesteswetenskappe en ekonomiese wetenskappe te ontwikkel. Werkgewende instellings behoort aan KVS aandag te skenk ten einde 'n gesonde en veilige werkomgewing te verseker. Hulle behoort bewus gemaak te word van hoe belangrik dit is om KVS te bestuur, en aangemoedig te word om mediese evaluasies saam met die huidige sielkundige evaluasies uit te voer. Dié diverse netwerke sal individue in staat stel om met die oog op die risiko van kardiovaskulêre siektes onder universiteitstudente - kontakte en alliansies te identifiseer en te ontwikkel (Ferris et al. 2011). Dit is in die belang van die individu dat professionele praktisyns binne hierdie netwerke 'n gemeenskaplike taal sal skep om studente bewus te maak van die stand van hul kardiovaskulêre gesondheid en hulle te onderrig in maniere waarop risiko's in dié verband geïdentifiseer kan word. Hierdie gemeenskaplike taal sal ook tydens die werwings- en keuringsprosesse, en tydens beroepsvoorligting nuttig wees vir kommunikasie tussen menslikehulpbronpraktisyns, industriële sielkundiges en gesondheidspraktisyns.

Volgens die resultate het byna 10\% van die steekproef hoër kardiale stres, 'n hoë harttempo en hoë bloeddrukvlakke gehad. Nie minder nie as $64.8 \%$ van die deelnemende studente het met 'n hoë Kardiale Stresindeks (KSI) gepresenteer en altesaam $61 \%$ van die deelnemers met hoër KSI-lesings het ook hoë bloeddruk gehad. Swak harttempoveranderlikheid, 'n hoë harttempo en hoë bloeddruk is by $9.9 \%$ van die studente gemeet. Die resultate dui dus daarop dat assessering en opvoeding van die jeug in verband met kardiovaskulêre gesondheid belangrik is. Hierdie bevindinge het ook potensiële implikasies vir beide praktyk en navorsing, veral indien toekomstige studies op grond van hierdie bevindinge ontwikkel word. Die bevindinge beklemtoon die noodsaaklikheid daarvan om jong Suid-Afrikaners bewus te maak van die gevaar van kardiovaskulêre siekte ten einde 'n afname teweeg te bring in die aantal mense wat jaarliks weens hartsiekte en verwante komplikasies sterf.

As 'n grootskaalse poging om hierdie bevolking te assesseer, sal praktiese opleiding om studente aangaande hul eie kardiovaskulêre gesondheid op te voed moontlik meer haalbaar wees as ' $n$ openbare gesondheidsveldtog. Beroepsvoorligters en sielkundiges wat met studente werk, behoort studente aan te raai om gesondheidsrisiko's 
in ag te neem wanneer hulle 'n beroep kies. Hierdie praktiese benadering, wat spesifiek op fisiologiestudente toegespits is, sal verdere vaardighede en kundigheid by hul beroepsontwikkeling voeg. Dit kan dalk raadsaam wees om uit te vind of studente 'n gesondheidsadviseur behoort te hê wat hulle meer oor 'n gesonde lewenstyl kan leer.

Uit bogenoemde resultate is dit duidelik dat dit vir universiteitstudente nodig is om hul lewenstyl te verander ten einde die algemene voorkoms van kardiovaskulêre siektes in hul geledere te voorkom. Een manier waarop hulle dit kan doen, is deur deel te neem aan liggaamlike aktiwiteite, wat in die geval van toestande soos kardiovaskulêre siekte, beroerte, diabetes en vetsug beide rehabiliterend en voorkomend kan wees (Mabry, Turner \& Hunt 2012; Van der Meer et al. 2012).

Kardiovaskulêre siekte, wat teenwoordig kan wees selfs as daar geen kliniese simptome of tekens voorkom nie, kan deur 'n lewenstylverandering, intervensie en medikasie voorkom word (Van der Meer et al. 2012). Die bevindinge van die studie en die literatuuroorsig beklemtoon die belangrikheid daarvan dat studente bewus van kardiovaskulêre risiko's gemaak word. Die navorsers is van mening dat alle jong SuidAfrikaners - en nie net dié op universiteits- en skoolvlak nie - bewus gemaak moet word van hul kardiovaskulêre risiko's en dat alle praktisyns in bogenoemde studievelde hulle moet beywer om, met behulp van 'n interdissiplinêre netwerk, individue en organisasies te bemagtig om 'n gesonder lewenstyl na te streef. Vanweë die klein steekproef wat gebruik is, kan dié studie nie na alle situasies veralgemeen word nie.

\section{Gevolgtrekking}

Hierdie navorsing het bevind dat $55.6 \%$ studente uit 'n groep van 162 aan hoë bloeddruk ly. Uit laasgenoemde groep was 18.9\% hipertensief (stadium 1-hipertensie) en die res $(81.1 \%)$ was prehipertensief. Byna $15.2 \%$ van die hele groep het verhoogde kardiale stres, 'n hoë hartkloptempo en hoë bloeddruk gehad en $64.8 \%$ van al die deelnemende studente se Kardiale Stresindeks (KSI) was hoog. Ongelukkig was die bloeddruk van $61 \%$ van die studente met verhoogde KSI-lesings ook te hoog en het $9.9 \%$ swak harttempoveranderlikheid, verhoogde harttempo en verhoogde bloeddruk getoon.

Die bevindinge beklemtoon die belangrike rol van KVSfaktore in die werkplek. Studente en organisasies moet bewus wees van die kompleksiteit van gesondheid en hoe dit die keuse van die regte loopbaan kan beïnvloed. Die gesondheid van werknemers het 'n ekonomiese impak op 'n organisasie se winsmarge. Die metode wat tydens hierdie navorsingstudie gebruik is, is aangewend om aan studente te wys hoe hulle meer kan leer oor die kwantifisering van KVS, asook om bewustheid van die risiko van KVS onder universiteitstudente te verhoog. KVS-faktore dra stellig by tot die meeste individuele verskille en moet dus by alle werkplekke in ag geneem word. In die beroeps- en arbeidsomgewing is dit die beroepspesialis en bestuur wat kennis sal moet neem van die biologiese impak van KVS binne die organisasie of onderneming. Dit is gevolglik belangrik om gesondheid en veiligheid gedurende beroepsvoorligting te fasiliteer ten einde studente aan te moedig om na hul gesondheid om te sien en bewus te wees van enige vorm van KVS wat hul loopbaankeuse kan beïnvloed.

Die feit dat daar voorheen byna uitsluitlik op KVS onder ouer groepe gefokus is, kan waarskynlik daaraan toegeskryf word dat jeug met gesondheid vereenselwig word. Hierdie data lig egter enkele ernstige probleme ten opsigte van die risiko van kardiovaskulêre siektes onder die jeug uit.

Bevordering van die bewustheid van KVS onder die jeug kan moontlik bydra tot die opbou van 'n hoogs doeltreffende arbeidsmag met bemagtigde werknemers wat binne die werkplek in beheer is van hul eie gesondheid. Dit sal werkgewende instansies in staat stel om in 'n uiters mededingende globale omgewing lewensvatbaar te bly.

\section{Beperkings van die studie}

Die beperkings van die studie en die feit dat slegs universiteitstudente by die navorsing betrokke was, maak dit moeilik om die resultate te veralgemeen. Daarbenewens was die betrokke studente almal uit slegs een universiteit in Suid-Afrika afkomstig. Dit sou gevolglik nie toepaslik wees om hierdie resultate te veralgemeen nie. Die outeurs erken dat daar beperkinge is met die interpretasie van die data, aangesien lewenstyl nie direk gemeet is nie. Die grootte van die steekproef was betreklik klein as die bevolking van die betrokke universiteit in ag geneem word. Verder was die meerderheid van die steekproef meisies, 'n feit wat die resultate tot 'n mate kon beïnvloed het. Dit word algemeen aanvaar dat vroue 'n gunstiger risikoprofiel as mans handhaaf wat kardiovaskulêre faktore betref. Nog 'n beperking is dat hierdie studie 'n deursneestudie was, wat korrelatiewe eerder as kousale bewyse lewer.

\section{Voorstelle vir verdere navorsing}

Verdere navorsing behoort te fokus op ander risikofaktore soos rook, 'n familiegeskiedenis van kardiovaskulêre probleme en nierfunksie. Daar bestaan ' $n$ behoefte aan verder sifting en opvoeding by hierdie populasie. Verdere navorsing behoort meer nasionale en internasionale universiteite in te sluit. Dié studie stel verskeie wetenskappe in staat om die beperkinge van die huidige navorsing te bowe te kom.

\section{Erkenning}

Die outeurs bedank die Departement Fisiologie, Universiteit van Pretoria en Neuro-Link vir bydrae tot hierdie navorsingsprojek.

\section{Mededingende belange}

Die outeurs verklaar hiermee dat hulle geen finansiële of persoonlike verbintenis het met enige party wat hulle 
nadelig of voordelig kon beïnvloed het in die skryf van hierdie artikel nie.

\section{Outeursbydrae}

Die aard van die bydraes van elke outeur, genoem op die lys, kan kortliks soos volg opgesom word: P.d.T. (Universiteit van Pretoria) projekleier; E.R. (Universiteit van Suid-Afrika) en Y.J. (Universiteit van Suid-Afrika) het gehelp met die skryf van die eerste weergawe van die manuskrip; N.C. (Universiteit van Pretoria) het bygestaan met die tegniese versorging; E.N. (Universiteit van Pretoria) redigering en die finale voorbereiding van die manuskrip; P.d.T., E.N. betrokke by die datasteekproefneming en uitvoering van die toetsprosedures; R.F. (Universiteit van Pretoria), E.K. (Universiteit van Pretoria) en W.F. (Universiteit van Pretoria) het konseptuele bydraes gemaak.

\section{Literatuurverwysings}

Ainsworth, B.E. \& Pettee Gabriel, K.K., 2009, 'Multiple approaches to reducing the burden of cardiovascular disease: Summary and conclusion', American Journal of Lifestyle Medicine 3(Suppl 1), S69-S72. http://dx.doi.org/10.1177/ 1559827609337586

Arnold, J., Randall, R., Silvester, J., Patterson, F., Robertson, I. \& Cooper, C., 2010, Work psychology, understanding human behaviour in the workplace, 5 th edn., Pearson Education Limited, London.

Berenson, G.S., Srinivasan, S.R., Bao, W., Newman, W.P., Tracy, R.E. \& Wattigney, W.A., 1998, 'Association between multiple cardiovascular risk factors and atherosclerosis in children and young adults', New England Journal of Medicine 338, 1650-1656. http://dx.doi.org/10.1056/NEJM199806043382302

Berenson, G.S., Wattigney, W.A., Tracy, R.E., Newman, W.P., Srinivasan, S.R., Webber, L.S., Dalferes Jr. E.R. \& Strong, J.P., 1992, 'Atherosclerosis of the aorta and coronary arteries and cardiovascular risk factors in persons aged 6 to 30 years and studied at necropsy (the Bogalusa Heart Study)', American Journal of Cardiology 70(9), 851-858. http://dx.doi.org/10.1016/0002 9149(92)90726-F

Bergh, Z., 2011, Introduction to work psychology, Oxford University Press, Cape Town. Brotman, D.J., Golden, S.H. \& Wittstein, I.S., 2007, 'The cardiovascular toll of stress', Lancet 370, 1089-1090. http://dx.doi.org/10.1016/S0140-6736(07)61305-1

Coetzee, M., Botha, J., Kiley, J.D. \& Truman, K., 2007, Practising education, training and development in South African organisations, Juta, Cape Town.

Daniels, S.R., Pratt, C.A. \& Hayman, L.L., 2011, 'Reduction of risk for cardiovascula disease in children and adolescents', Circulation 124, 1673-1686. http://dx.doi org/10.1161/CIRCULATIONAHA.110.016170

Die Wet op Beroepsgesondheid en Veiligheid (Wet nr. 85 van 1993) besoek by http:// www.labour.gov.za/legislation/acts/occupational-health-and-safety/read-online/ amended-occupational-health-and-safety-act.

Du Toit, P.J., Kruger, E., Govender, C., Henning, E., Kleynhans, M., Wood, P.S., De Villiers, N., Van Rooyen, J.M. Fletcher, L. \& Grant, C.C., 2012, 'Cardiovascular
health screening among South African students', African Journal for Physical, Health Education, Recreation and Dance, Supplement (March), 59-168.

Ferris, G.R., Kane, R.E., Summers, J.K. \& Munyon, T.P., 2011, 'Psychological and physiological health and well-being implications of political skill: Toward a multi-mediation organizing framework', Research in Occupational Stress and Well Being 9, 63-107. http://dx.doi.org/10.1108/S1479-3555(2011) and Well Bein 0000009007

Ferris, G.R., Treadway, D.C., Perrewé, P.L., Brouer, R.L., Douglas, C. \& Lux, S., 2007, 'Political skill in organizations', Journal of Management 33, 290-320. http://dx.doi.org/10.1177/0149206307300813

Gaziano, J.M., 1998, 'When should heart disease prevention begin?', New England Journal of Medicine 338, 1690-1692. http://dx.doi.org/10.1056/ NEJM199806043382310
Giri, S., Sharma, S.R., Timalsina, S., Yadav, V., Koirala, S., Kumar, A., Neupane, S. \& Neupane, M., 2012, 'Cardiovascular health risk behavior among medical students in a teaching hospital', Journal of Nepal Health Research Council 10(22), 187-91.

Hughes, R., Kinder, A. \& Cooper, C. L., 2012, International handbook of workplace trauma support, Wiley, West Sussex, UK. http://dx.doi.org/10.1002/9781119943242

JNC 7 Express, 2003, 'The seventh report of the joint national committee on prevention, detection, evaluation, and treatment of high blood pressure', viewed 28 November 2013 from http://www.nhlbi.nih.gov/guidelines/hypertension/ express.pdf.

Kivimäki, M., Leino-Arjas, P., Luukkonen, R., Riihimäi, H., Vahtera, J. \& Kirjonen, J., 2002, 'Work stress and risk of cardiovascular mortality: Prospective cohor study of industrial employees', British Medical Journal 325(7369), 857-861. http://dx.doi.org/10.1136/bmj.325.7369.857

Mabry, G., Turner, L. \& Hunt, S., 2012, 'Application of self-efficacy theory to increase physical activity in the workplace', Arkansas Journal 47(1), 22-35.

McGill Jr., H.C., McMahan, C.A. \& Gidding, S.S., 2008, 'Preventing heart disease in the 21st century: Implications of the Pathobiological Determinants of Atherosclerosis in Youth (PDAY) Study', Circulation 117, 1216-1227. http://dx.doi.org/10.1161/ CIRCULATIONAHA.107.717033

McMahan, C.A., Gidding, S.S., Malcom, G.T., Tracy, R.E., Strong, J.P. \& McGill Jr., H.C. 2006, 'Pathobiological Determinants of Atherosclerosis in Youth Risk Scores are associated with early and advanced atherosclerosis', Pediatrics 118(4), are associated with early and advanced atheroscler
$1447-1455$. http://dx.doi.org/10.1542/peds.2006-0970

Mostert, F.F., Rothmann, S., Mostert, K. \& Nell, K., 2008, 'Outcomes of occupational stress in a higher education institution', Southern African Business Review 12(3), stress in a $102-127$.

Muchinsky, P.M., 2006, Psychology applies to work, 8th edn., Thomson, Belmont, CA.

Nevid, J.S., Rathus, S.A. \& Greene, B., 2008, Abnormal psychology in a changing world, 8th edn., Pearson Education Inc., Upper Saddle River, NJ.

Onyishi, I.E. \& Ogbodo, E., 2012, 'The contributions of self-efficacy and perceived organisational support when taking charge at work', SA Journal of Industrial Psychology 38(1), 1-11. http://dx.doi.org/10.4102/sajip.v38i1.979

Pallant, J., 2005, SPSS survival manual, 2nd edn., McGraw-Hill, New York, NY.

Pestana, J.A., Steyn, K., Leiman, A. \& Hartzenberg, G.M., 1996, 'The direct and indirect costs of cardiovascular disease in South Africa in 1991', South African Medical Journal 86(6), 679-684.

Rindfleisch, A., Malter, A.J., Ganesan, S. \& Moorman, C., 2008, 'Cross-sectional versus longitudinal survey research: Concepts, findings, and guidelines', Journal of Marketing Research 45, 261-279. http://dx.doi.org/10.1509/jmkr.45.3.261

Rudack, P., 2005, Viport scientific background 'Heart rate variability and health status', Institute of Sport Medicine, University Hospital, Muenster, Germany.

Rustagi, N., Taneja, D.K., Mishra, P. \& Ingle, G.K., 2011, 'Cardiovascular risk behavior among students of a medical college in Delhi', Indian Journal of Community

Schanall, P.L., Belkic, K.L., Landsbergis, P.A. \& Baker, D.B., 2000, 'The workplace and cardiovascular disease', Occupational Medicine 15(1), 97-122.

Schultz, D.P. \& Schultz, S.E., 2011, Psychology and work today: An introduction to industrial and organizational psychology, 10th edn, Pearson, Boston, MA.

Steptoe, A., Wardle, J., Cui, W., Bellisle, F., Zotti, A., Baranyai, R. \& Sanderman, R., 2002 , 'Trends in smoking, diet, physical exercise, and attitudes towards health in European university students from 23 countries, 1990-2000', Preventive Medicine 35, 97-104. http://dx.doi.org/10.1006/pmed.2002.1048

Tibazarwa, K., Ntyintyane, L., Sliwa, K., Gerntholtz, T., Carrington, M., Wilkinson, D. \& Stewart, S., 2009, 'A time bomb of cardiovascular risk factors in South Africa: Results from the heart of Soweto study "Heart Awareness Days"\#', International Journal of Cardiology 132, 233-239. http://dx.doi.org/10.1016/j. ijcard.2007.11.067

Umetani, K., Singer, D.H., McCraty, R. \& Atkinson, M., 1998, 'Twenty-four hour time domain heart rate variability and heart rate: relations to age and gender over nine decades', Journal of the American College of Cardiology 31(3), 593-601. http://dx.doi.org/10.1016/S0735-1097(97)00554-8

Van der Meer, R.W., Lamb, H.J., Smit, J.W.A. \& De Roos, A., 2012, 'MR imaging evaluation of cardiovascular risk in metabolic syndrome', Radiology 264(1), 21-37. http://dx.doi.org/10.1148/radiol.12110772

Voltmer, E. \& Spahn, C., 2011, 'Work-related behaviour and experience patterns of entrepreneurs compared to teachers and physicians', Occupational Environment entrepreneurs compared to teachers and physicians', Occupational
Health 84, 479-490. http://dx.doi.org/10.1007/s00420-011-0632-9

Wright, T.A. \& Huang, C., 2012, 'The many benefits of employee well-being in organizational research', Journal of Organizational Behavior 33, 1188-1192. http://dx.doi.org/10.1002/job.1828 